\title{
PENGARUH METODE KULIAH ONLINE TERHADAP TINGKAT PEMAHAMAN MATERI KULIAH HUKUM INVESTASI PADA MAHASISWA UNIVERSITAS TEKNOLOGI INDONESIA
}

\author{
Desak Made Rai Ningsih \\ Universitas Teknologi Indonesia Denpasar \\ e-mail: \\ dsakningsih@gmail.com
}

\begin{abstract}
Background. Online lectures are one of the most effective lecture methods during the covid-19 pandemic. Online lectures can be done using internet technology and using an Android smartphone or computer. Aim. The research objective is to determine the effect of online lecture methods on the level of student understanding of investment law courses at the University of Technology Indonesia. Method. This research uses quasyexperiment method with one group pre-pos tes only design. The number of respondents was 36 who were students who took investment law courses. Retrieval of data using online quizzes as pre-pos tes scores. The statistical test used is paired t- test. Results. Statistical test results obtained $p$-value of 0.001 . Conclusion. There is an influence of online lecture methods on the level of student understanding of investment law courses at the University of Technology Indonesia.
\end{abstract}

Keywords: online lecture, level of understanding

\begin{abstract}
Abstrak: Pendahuluan. Perkuliahan online saat ini merupakan salah satu metode perkuliahan yang efektif selama masa pandemic covid-19. Perkuliahan online dapat dilakukan dengan menggunakan teknologi internet dan menggunakan smartphone android ataupun komputer. Tujuan. Tujuan penelitian adalah untuk mengetahui pengaruh metode kuliah online terhadap tingkat pemahaman mahasiswa tentang materi kuliah hukum investasi di Universitas Teknologi Indonesia. Metode. Penelitian ini menggunakan metode quasy-eksperiment dengan desain one group pre-pos tes only. Jumlah responden sebanyak 36 yang merupakan mahasiswa yang mengambil mata kuliah hukum investasi. Pengambilan data dengan menggunakan kuis online sebagai nilai pre-pos tes. Uji statistik yang digunakan adalah uji paired t-test. Hasil. Hasil uji statistic didapatkan nilai $p$-value 0.001. Kesimpulan. Ada pengaruh metode kuliah online terhadap tingkat pemahaman mahasiswa tentang mata kuliah hukum investasi di Universitas Teknologi Indonesia.
\end{abstract}

Kata kunci: kuliah online, tingkat pemahaman 


\section{PENDAHULUAN}

Pandemik covid-19 yang sedang dialami sangat mempengaruhi berbagai hal termasuk pendidikan. Salah satu standar pencegahan yang dilakukan oleh pemerintah adalah social distancing. Social distancing juga berarti bahwa perkuliahan tatap muka seperti biasa yang dilakukan sebelumnya tidak boleh dilakukan. Penerapan lingkungan perkuliahan yang sesuai dengan anjuran pemerintah salah satunya yaitu perkuliahan online menggunakan teknologi internet (Setiawan, 2018). Mata kuliah hukum investasi sebelumnya merupakan mata kuliah dengan metode konvensional atau tatap muka. Karena mata kuliah hukum investasi tidak memerlukan praktik laboratorium maka dapat dilakukan sepenuhnya dengan menggunakan metode perkuliahan online.

Perkuliahan online dilakukan untuk mengusahakan kualitas pembelajaran bagi peserta didik dalam masa pandemi. Perkuliahan online merupakan proses edukasi dengan menggunakan media elektronik dan teknologi internet (Wicaksono, Winarno, \& Sunyoto, 2015). Pembelajaran dengan menggunakan metode e-learning merupakan salah satu metode pembelajaran yang efektif karena memanfaatkan teknologi informasi dan juga komunikasi dengan optimal (Hanum, 2013). E-learning juga merupakan salah satu sarana pendidikan yang menggabungkan antara komunikasi, motivasi diri, efisiensi, dan juga teknologi (Behera, S, 2013). Dalam perkuliahan online dosen memiliki peran sebagai pemberi materi pembelajaran, stimulus dan arahan bagi mahasiswa. Stimulus yang diberikan dimaksudkan untuk membantu mahasiswa dalam memahami materi perkuliahan, sehingga memberikan hasil akhir berupa perubahan perilaku dalam belajar dan penguasaan substansi dengan baik (Yuniarti, 2010).

Keunggulan dari perkuliahan online adalah dapat memberikan pengalaman yang berbeda dalam perkuliahan, perkuliahan dapat dilakukan dimana saja dengan menggunakan komputer ataupun handphone android, menekan kemandirian dalam belajar dan juga standar kualitas dari pemberian materi lebih konsisten (Yuniarti, 2010).

Sistem e-learning dapat menciptakan individuasi, pengayaan, akselerasi, perluasaan, produktivitas dan efektifitas dalam pembelajaran sehinggga kualitas pendidikan dapat meningkat (Yuniarti, 2010). Hal ini dikarenakan pada penyampaian data dengan media lebih menyenangkan, konten materi yang diberikan dengan jelas akan digemari sehingga mahasiswa memiliki rasa ingin tahu yang tinggi (Mustofa, Chodzirin, Sayekti, \& Fauzan, 2019; Prayudi, 2009). Mahasiswa mencari sendiri pengetahuan yang dibutuhkan melalui fasilitas internet dan arahan dari dosen. Selain itu, metode ini juga membantu mahasiswa tersebut dapat belajar dimana saja dan kapan saja (Fitriasari, Tanzimah, \& Sari, 2018). Dampak dari perkuliahan online ini diharapkan dapat memotivasi mahasiswa dalam peningkatan kualitas pembelajaran, kemandirian belajar, selain itu dosen juga diharapkan mampu memiliki materi ajar yang lebih berkualitas dan dapat dilaksanakan kapanpun dan dimana saja (Prayudi, 2009).

Evaluasi atau penilaian keberhasilan dari pemberian perkuliahan dengan online dapat dilakukan dengan berbagai cara yaitu: Pemberian tugas dan juga kuis online. Tugas yang diberikan dapat berupa materi yang telah diajarkan. Kuis online juga merupakan salah satu teknik evaluasi yang objektif dan dapat digunakan 
sebagai pre tes dan juga pos tes sebagai gambaran pemahamanan peserta didik (Turrahma, Satyariza, \& Ibrahim, 2018).

Berdasarkan pemikiran di atas atikel ini dimaksudkan untuk menguraikan dan menjelaskan dampak metode kuliah online terhadap tingkat pemahaman mahasiswa tentang materi kuliah hukum investasi.

\section{METODE}

Metode penelitian yang digunakan adalah quasy-eksperiment one group pre-pos tes design. Penelitian ini dilakukan pada 36 mahasiswa semester 6 yang mendapatkan mata kuliah hukum investasi. Perkuliahan membahas tentang kebijakan didalam investasi dengan capaian pembelajaran supaya mahasiswa mampu memahami tentang koordinasi dan pelaksana kebijakan penanaman modal dan. penyelenggaraan urusan penanaman modal.

Perkuliahan hukum investasi sebelumnya diberikan dengan metode konvensional atau tatap muka di kelas, dan dalam penelitian ini merupakan pertama kali perkuliahan menggunakan metode online. Sehingga dilakukan beberapa perubahan dalam cara penyajian materi dan juga pengukuran ketercapaian tujuan pembelajaran.

Strategi perkuliahan online diberikan melalui aplikasi google classroom selama 100 menit. Topik perkuliahan diberikan melalui share screen dan secara virtual menggunakan google meet peneliti menjelaskan topic pembelajaran tersebut. Kemudian kepada mahasiswa diberikan kesempatan untuk bertanya secara virtual maupun melalui kolom chat. Diskusi membahas materi juga dilakukan dalam kesempatan tersebut.

Capaian pembelajaran diukur melalui hasil pengukuran pre tes dan pos tes. Materi pre tes dan pos tes paralel dengan capaian pembelajaran topik kebijakan di dalam investasi. Pre tes dan pos tes diberikan melalui aplikasi Sevima. Nilai pre tes dan pos tes muncul setelah semua jawaban telah diisi dan dikumpulkan. Jumlah pertanyaan di dalam pre tes dan pos tes adalah sama yaitu sebanyak 20 soal diantaranya 10 soal tentang koordinasi dan pelaksana kebijakan penanaman modal dan 10 soal tentang penyelenggara urusan penanaman modal. Pada aplikasi ini telah diatur waktu pengisian yaitu 15 menit untuk pre tes dan 15 menit untuk pos tes.

Pengaturan waktu pada pre tes dan pos tes membantu peneliti untuk menghindari kemungkinan terjadinya kecurangan dari mahasiswa. Nilai pre tes dan pos tes dihitung dari jumlah jawaban benar. Hasil penilaian dianalisis dengan menggunakan aplikasi SPSS, dan uji statistik yang digunakan untuk menganalisis data adalah uji paired t-test karena data berdistribusi normal dengan nilai shapirowilk $p=>0.05$.

\section{HASIL DAN PEMBAHASAN}

Hasil analisis menunjukkan peningkatan rata-rata nilai pre dan pos tes sebagaimana pada Tabel 1. 
Tabel 1. Distribusi Nilai Pre dan Pos Tes Materi Hukum Investasi

\begin{tabular}{|c|c|c|c|}
\hline No Responden & Pre & Post & Gain \\
\hline 1 & 20 & 65 & 45 \\
\hline 2 & 20 & 70 & 50 \\
\hline 3 & 25 & 65 & 40 \\
\hline 4 & 25 & 65 & 40 \\
\hline 5 & 25 & 70 & 45 \\
\hline 6 & 25 & 70 & 45 \\
\hline 7 & 30 & 65 & 35 \\
\hline 8 & 30 & 65 & 35 \\
\hline 9 & 30 & 65 & 35 \\
\hline 10 & 30 & 70 & 40 \\
\hline 11 & 35 & 65 & 30 \\
\hline 12 & 35 & 65 & 30 \\
\hline 13 & 35 & 65 & 30 \\
\hline 14 & 35 & 70 & 35 \\
\hline 15 & 40 & 70 & 30 \\
\hline 16 & 40 & 70 & 30 \\
\hline 17 & 40 & 70 & 30 \\
\hline 18 & 40 & 70 & 30 \\
\hline 19 & 40 & 70 & 30 \\
\hline 20 & 40 & 70 & 30 \\
\hline 21 & 45 & 70 & 25 \\
\hline 22 & 45 & 70 & 25 \\
\hline 23 & 45 & 70 & 25 \\
\hline 24 & 45 & 70 & 25 \\
\hline 25 & 45 & 70 & 25 \\
\hline 26 & 45 & 70 & 25 \\
\hline 27 & 45 & 70 & 25 \\
\hline 28 & 50 & 85 & 35 \\
\hline 29 & 50 & 85 & 35 \\
\hline 30 & 50 & 85 & 35 \\
\hline 31 & 50 & 85 & 35 \\
\hline 32 & 50 & 85 & 35 \\
\hline 33 & 50 & 85 & 35 \\
\hline 34 & 50 & 85 & 35 \\
\hline 35 & 55 & 70 & 15 \\
\hline 36 & 55 & 90 & 35 \\
\hline Mean & 39.31 & 72.22 & 32.92 \\
\hline
\end{tabular}

Tabel 1 menunjukkan rata-rata nilai pre tes adalah 39.31 dan terjadi peningkatan sebesar 32.91 pada nilai pos tes. Peningkatan ini cukup besar yaitu 
$83 \%$. Bahkan apabila dilihat pada mahasiswa yang sebelumnya memperoleh nilai rendah (responden 1-6) peningkatan dari pre tes ke pos tes mencapai 3 kali lipat. Peningkatan ini menandakan bahwa metode pembelajaran online yang dilakukan tidak menghambat pemahaman mahasiswa terhadap materi perkuliahan.

Selanjutnya dipaparkan gambaran perbandingan hasil pre tes dan pos tes dengan menggunakan klasifikasi: Baik, cukup dan kurang. Klasifikasi ini dibuat untuk menggambarkan perbedaan dengan lebih jelas dalam kelompok. Klasifikasi baik, cukup dan kurang diadopsi dari Arikunto (2013) yang menyatakan bahwa hasil ukur pengetahuan dapat dikelompokkan menjadi 3 kategori yaitu: Baik $(76 \%$ $100 \%)$, Cukup (56\%-75\%) dan kurang (<=55\%). Klasifikasi nilai mahasiswa dalam 3 kelompok dapat dilihat pada Tabel 2.

Tabel 2. Klasifikasi Nilai Pre Tes dan Pos Tes Mata Kuliah Hukum Investasi

\begin{tabular}{ccccccc}
\hline \multirow{2}{*}{ Variable } & \multicolumn{2}{c}{ Baik } & \multicolumn{2}{c}{ Cukup } & \multicolumn{2}{c}{ Kurang } \\
\cline { 2 - 7 } & $\boldsymbol{n}$ & $\%$ & $\boldsymbol{N}$ & $\%$ & $\boldsymbol{n}$ & $\%$ \\
\hline Pre tes & 0 & $0 \%$ & 22 & $61.1 \%$ & 14 & $38.9 \%$ \\
Postes & 8 & $22.2 \%$ & 28 & $77.8 \%$ & 0 & $0 \%$ \\
\hline
\end{tabular}

Tabel 2 menunjukkan peningkatan secara umum hasil test pre-pos mahasiswa. Pada pre tes nilai mahasiswa persentase terbesar, $61.1 \%$ termasuk kriteria cukup, 38.9\% kurang, dan tidak ada yang masuk kategori baik. Pada pos tes sebagian besar mendapatkan nilai cukup (77.8\%) dan kategori baik $22.2 \%$, sedangkan untuk kategori kurang tidak ada. Hasil ini menunjukkan tidak ada mahasiswa yang memiliki nilai kurang pada hasil pos tes, dan hal ini mengindikasikan peningkatan hasil belajar siswa setelah mengikuti pembelajaran online.

Untuk memastikan apakah ada pengaruh signifikan kuliah online terhadap tingkat pemahaman materi kuliah hukum investasi maka dilakukan uji paired t-test dengan hasil sebagai mana pada Tabel 3.

Tabel 3. Signifikansi Perbedaan Nilai Pre - Pos Tes Berdasarkan Uji Paired T-Test

\begin{tabular}{|c|c|c|c|c|c|}
\hline \multirow{2}{*}{ Variabel } & \multirow{2}{*}{ Mean } & \multirow{2}{*}{$\begin{array}{c}\text { Std. } \\
\text { deviation }\end{array}$} & \multicolumn{2}{|c|}{$95 \% \mathrm{Cl}$} & \multirow{2}{*}{$p$-value } \\
\hline & & & Lower & Upper & \\
\hline Pre-post & -32.917 & 7.109 & -35.322 & -30.511 & 0.001 \\
\hline
\end{tabular}

Tabel 3 menunjukkan bahwa terdapat perbedaan yang signifikan antara nilai pre dan post mahasiswa, ditunjukkan dengan nilai $p$-value $0.001<0.005$, yang berarti bahwa perbedaan nilai pre dan post terjadi bukan karena kebetulan tetapi bahwa pembelajaran yang dilakukan membawa hasil berbeda dengan metode sebelumnya.

Hasil penelitian ini sejalan dengan penelitian dari Rozmita Dewi Yuniarti (2010) yang menyatakan bahwa nilai ujian mahasiswa dengan menggunakan metode e-learning cukup baik, bahkan nilai yang diperoleh mahasiswa lebih tinggi 
pada mata kuliah lain yang dilakukan dengan kuliah tatap muka. Disebutkan bahwa perkuliahan dengan menggunakan sistem e-learning dapat membantu mahasiswa belajar secara mandiri sekaligus membantu mahasiswa tersebut memiliki rasa ingin tahu yang tinggi.

Perkuliahan online pertama kali dilakukan pada perkuliahan hukum investasi. Awalnya peneliti ragu untuk memberikan perkuliahan dengan metode online tapi ternyata perkuliahan dapat dilaksanakan dengan baik. Peran dosen sebagai pemberi materi tetap berjalan dengan baik secara virtual dan dengan bantuan fitur share screen dosen dapat memberikan penjelasan terkait topik perkuliahan yang diberikan.

Evaluasi ketercapaian tujuan pembelajaran juga dapat tetap diukur menggunakan aplikasi yang tersedia sehingga dosen tetap dapat mengetahui tingkat pemahaman mahasiswanya terhadap substansi perkuliahan, walaupun dengan strategi perkuliahan online.

Perkuliahan online tidak luput dari beberapa masalah. Dalam perkuliahan online yang dilakukan terjadi hambatan berupa suara yang tidak terdengar dengan jelas akibat sinyal jaringan internet yang tidak kuat. Salah satu faktor yang mempengaruhi adalah terbatasnya jaringan internet terutama di daerah pedesaan Provinsi Bali. Masalah ini juga merupakan masalah nasional dan banyak dikeluhkan oleh beberapa peneliti lainnya. Disebutkan bahwa terdapat kendala yang mempengaruhi perkuliahan online, yaitu: Jaringan internet yang lemah (Mohammad Yazdi, 2012), keterbatasan dari kuota internet dalam mengakses perkuliahan (Setiawan, 2018).

Lebih lanjut Wardani dkk, yang menyatakan bahwa salah satu kekurangan dari metode pembelajaran dari e-learning adalah kurangnya interaksi langsung antara mahasiswa dan dosen (Wardani, Toenlioe, \& Wedi, 2018). Kekurangan in memang akan sangat mempengaruhi keberhasilan pembelajaran, tetapi dengan bantuan aplikasi teknologi tertentu interaksi yang intensif juga dapat dilakukan, misalnya melalui penggunaan Microsoft Teams, Zoom atau aplikasi komunikasi online lainnya. Dosen masih dapat berinteraksi secara virtual dengan seluruh mahasiswa dengan menggunakan beberapa aplikasi tersebut. Sehingga, proses pembelajaran dengan metode kuliah online dapat dilakukan dengan baik.

\section{KESIMPULAN}

Hasil penelitian ini menunjukkan pengaruh positif dan signifikan metode perkuliahan online terhadap tingkat pemahaman mahasiswa tentang hukum investasi. Hal ini menunjukkan bahwa metode perkuliahan online mempunyai potensi menjadi strategi pembelajaran selama pandemik covid-19. Capaian tujuan pembelajaran tetap tercapai meskipun penjelasan diberikan menggunakan komunikasi virtual. Selain meningkatkan pemahaman mahasiswa terhadap substansi perkuliahan yang diberika, perkuliahan online juga mampu meningkatan kemampuan mahasiswa dan dosen dalam bidang penggunaan teknologi dan informasi yang berkembang pesat seiring dengan perkembangan zaman. 


\section{REFERENSI}

Arikunto, S. (2013). Prosedur penelitian: Suatu pendekatan praktik (15th ed.). Jakarta: Rineka Cipta.

Behera, S, K. (2013). E- and m-learning: A comparative study. International Journal on New Trends in Education and Their Implications (IJONTE), Vol. 4(4), 214.

Fitriasari, P., Tanzimah, T., \& Sari, N. (2018). Kemandirian belajar mahasiswa melalui blended learning pada mata kuliah metode numerik. Jurnal Elemen, Vol. 4(1), 1. https://doi.org/10.29408/jel.v4i1.439.

Hanum, N. S. (2013). Keefetifan e-learning sebagai media pembelajaran (studi evaluasi model pembelajaran e-learning SMK Telkom Sandhy Putra Purwokerto). Jurnal Pendidikan Vokasi, Vol. 3(1), 90-102. https://doi.org/ 10.21831/jpv.v3i1.1584.

Mohammad Yazdi. (2012). E-learning sebagai media pembelajaran interaktif berbasis teknologi informasi. Jurnal Ilmua Foristek, Vol. 2 (1)(1), 143-152.

Mustofa, M. I., Chodzirin, M., Sayekti, L., \& Fauzan, R. (2019). Formulasi model perkuliahan daring sebagai upaya menekan disparitas kualitas perguruan tinggi. Walisongo Journal of Information Technology, Vol. 1(2), 151. https://doi.org/10.21580/wjit.2019.1.2.4067.

Prayudi, Y. (2009). Prosiding seminar nasional aplikasi teknologi informasi (SNATI). Kajian Awal: E-Learning REadiness Index (ELRI) sebagai model bagi evaluasi e-learning pada sebuah institusi, 2009(Snati). Retrieved from http://journal.uii.ac.id/index.php/Snati/article/view/953/909.

Setiawan, D. (2018). Perspektif e-learning dosen program studi sistem informasi UNIPMA. Journal of Computer, Information System, \& Technology management, Vol. 1(2), 1-6.

Turrahma, A., Satyariza, E. N., \& Ibrahim, A. (2018). Pemanfaatan E-Learning Berbasis Lcms Moodle dalam peningkatan efisiensi dan efektivitas serta kualitas media pembelajaran siswa di Man Sakatiga. Jurnal Nasional Pendidikan Teknik Informatika (JANAPATI), Vol. 6(3), 327. https://doi.org/ 10.23887/janapati.v6i3.12672.

Wardani, D. N., Toenlioe, A. J. E., \& Wedi, A. (2018). Daya tarik pembelajaran di era 21 dengan blended learning. Jurnal Kajian Teknologi Pendidikan (JKTP), Vol. 1(1), 13-18.

Wicaksono, A. R., Winarno, W. W., \& Sunyoto, A. (2015). Perancangan dan implementasi e-learning pendukung project. Seminar Nasional Teknologi Informasi Dan Komunikasi, 2015(Sentika), 333-343.

Yuniarti, R. D. (2010). Meningkatkan kualitas pembelajaran di Prodi Tata Niaga Jurusan pendidikan ekonomi FPEB-UPI. 8(16), 66-77. 